\title{
The plasmin cascade and matrix metalloproteinases in non-small cell lung cancer
}

\author{
G Cox, W P Steward, K J O’Byrne
}

There are several steps involved in the metastatic spread of cancer from the primary tumour to a secondary remote site. Firstly, the cancer cells have to escape from the primary site and then intravasate into the blood or lymphatic circulation. The cells must survive transportation in the circulation before extravasating at a distant site. These cells then need to establish themselves at the new site before growth and replication can occur to form a metastatic colony. During this time the malignant cell has to avoid destruction by the host immune system. Vital to the growth of both the primary and metastatic disease is the capacity of the tumour to induce breakdown of the extracellular matrix (ECM) and the formation of a blood supply through new blood vessel formation, a process known as angiogenesis.

The ECM is a framework of proteins and proteoglycans secreted by and surrounding stromal fibroblasts. It gives structural support to cells and plays a central role in cell adhesion, differentiation, proliferation, and migration. The ECM is separated from epithelial cells by a basement membrane which is made up of type IV collagen and creates a scaffold upon which heparan sulphate, laminin, and other components are arranged. ${ }^{1}$ The turnover of the ECM usually occurs slowly in mature tissues but is accelerated in wound healing, arthritic joint destruction, uterine involution, and malignancy. ${ }^{2}$ All benign disorders demonstrate a continuous basement membrane ${ }^{3}$ whereas a consistent finding in invasive tumours is penetration of the basement membrane. ${ }^{4}$ For penetration of the basement membrane and intravasation to occur there must be alteration of the cell-cell and cell-matrix attachment followed by a proteolytic alteration of the ECM and migration of the tumour cell through the modified matrix. Malignant cells demonstrate repeated attachment and release from the $\mathrm{ECM}^{5}$ as well as enhanced proteolysis and migration through matrix barriers. There are several families of enzymes capable of degrading the ECM including the serine proteases, cathepsins, and the matrix metalloproteinases.

Department of

Medical Oncology,

Osborne Building,

Leicester Royal

Infirmary, Leicester

LE1 5 WW, UK

G Cox

W P Steward

K J O’Byrne

Correspondence to: Dr KJ O'Byrne.

Received 5 May 1998 Returned to author 6 July 1998

Revised manuscript received

1 October 1998

Accepted for publication

15 October 1998 \begin{abstract}
uPA generally increases plasmin for ECM degradation whilst tPA primarily increases plasmin for thrombolysis.

Serine proteases and their inhibitors
Plasmin is a $90 \mathrm{kDa}$ serine protease capable of activating prometalloproteinases and degradplasminogen activator (uPA) and tissue-type plasminogen activator (tPA) are enzymes that catalyse the conversion of the inactive zymogen ing fibrin, fibronectin, and vitronectin. Plasmin
\end{abstract}

uPA consists of two polypeptide chains linked by a disulphide bridge. The C-terminal sequence contains the serine protease domain whilst the $\mathrm{N}$-terminal sequence consists of a growth factor domain and a kringle. uPA expression is regulated by hormones, growth factors and cytokines. ${ }^{6}$ The conversion of single chain pro-uPA to active two chain uPA is catalysed by plasmin, ${ }^{7}$ coagulation factor XIIa, ${ }^{8}$ cathepsins B and L, ${ }^{910}$ and prostatic specific antigen. ${ }^{11}$ The growth factor domain of uPA binds to a urokinase receptor (UPAR), a protein attached to the cell membrane by a glycosyl phosphatidyl inositol anchor. uPAR is capable of binding both pro-uPA and uPA. ${ }^{12}$ uPAR binding uPA increases plasmin activity at the cell surface. ${ }^{73}$ Plasmin bound to the cell surface is protected from inhibition by $\alpha_{2}$-antiplasmin ${ }^{14}$ and this helps to restrict proteolysis to this site.

The family of serine protease inhibitors (serpins) includes $\alpha_{2}$-antiplasmin and the plasminogen activator inhibitors PAI-1 and PAI-2. These inhibitors contain a reactive centre peptide loop that acts as a pseudo-substrate for proteases. The loop forms a 1:1 stable stoichiometric complex with the protease and inactivates it. ${ }^{15}$ After binding, PAI-2 is cleaved and inactivated. PAI-1 and PAI-2 can combine with the uPA/uPAR complex ${ }^{16}$ although at a slower rate than with uPA alone. ${ }^{17}$ This new complex inhibits ECM degradation. ${ }^{18}$ The $\mathrm{uPA} / \mathrm{uPAR} / \mathrm{PAI}$ complex is endocytosed and degraded ${ }^{19}$ when associated with a member of the low density lipoprotein receptor family. ${ }^{20}$

\section{Matrix metalloproteinases and their inhibitors}

The matrix metalloproteinases (MMPs) are a family of zinc atom dependent endopeptidases that are capable of digesting ECM and basement membrane components under physiological conditions. They all contain a catalytic domain that can degrade at least one component of the ECM. They also have a distinctive PRCGVPD sequence in the pro-enzyme domain that, in the latent state, has an unpaired cysteine residue that can occupy a coordination position on the zinc atom. The disruption of this sulphur-zinc "bond" activates the enzyme. Tissue inhibitors of metalloproteinases (TIMPs) are specific endogenous inhibitors of MMPs. ${ }^{21} 22$ MMP family members differ structurally from each other by the presence or absence of other domains that affect substrate specificity, inhibitor binding, and ECM binding. Most MMPs are secreted as latent pro-enzymes that require activation by the cleavage of an N-terminal sequence ${ }^{21}$ and are classically grouped by their substrate specificity. 
Table 1 Matrix metalloproteinase (MMP) family

\begin{tabular}{|c|c|c|c|}
\hline Major subsets & Name & MMP nо. & Major substrates \\
\hline \multicolumn{4}{|c|}{ Classic matrix metalloproteinase (MMP) members: } \\
\hline \multirow[t]{3}{*}{ Collagenases } & Interstitial collagenase (fibroblast type) & MMP-1 & Fibrillar collagens \\
\hline & Neutrophil collagenase & MMP-8 & Fibrillar collagens \\
\hline & Collagenase- 3 & MMP-13 & Fibrillar collagens \\
\hline \multirow[t]{3}{*}{ Stromelysins } & Stromelysin-1 & MMP-3 & Laminin, fibronectin, proteoglycans, type IV \\
\hline & Stromelysin-2 & MMP-10 & collagens \\
\hline & Matrilysin & MMP-7 & $\begin{array}{l}\text { Proteoglycans, type IV collagens, gelatins, ECM } \\
\text { glycoproteins, elastin }\end{array}$ \\
\hline \multirow[t]{2}{*}{ Gelatinases } & Gelatinase A & MMP-2 & Type I and IV collagens, gelatin \\
\hline & Gelatinase B & MMP-9 & Type IV and V collagens, gelatin \\
\hline \multirow{3}{*}{ Elastases } & Metalloelastase & MMP-12 & Elastin \\
\hline & ? & MMP-18 & Elastin \\
\hline & ? & MMP-19 & Elastin \\
\hline \multicolumn{4}{|c|}{ Novel matrix metalloproeinase family members: } \\
\hline RXKR secreted type & Stromelysin-3 & MMP-11 & $\begin{array}{l}\text { Laminin, fibronectin, proteoglycans, alpha } \\
\text { 1-antitrypsin }\end{array}$ \\
\hline \multirow[t]{4}{*}{ RXKR membrane type } & MT1-MMP & MMP-14 & $\begin{array}{l}\text { Gelatinase A, fibrillar collagens, ECM } \\
\text { glycoproteins, proteoglycans }\end{array}$ \\
\hline & MT2-MMP & MMP-15 & ? \\
\hline & MT3-MMP & MMP-16 & Gelatinase A \\
\hline & MT4-MMP & MMP-17 & ? \\
\hline
\end{tabular}

Adapted from Stetler-Stevenson $e t a l^{208}$ and Chambers $e t a l{ }^{2}$

There is also a subgroup of MMPs that are cell membrane bound and a subgroup that are secreted in an activated form. These latter two subgroups contain a 10 amino acid furin-type protease recognition sequence RXKR. Membrane type 1-MMP (MT1-MMP) has a transmembrane domain and is capable of activating progelatinase $\mathrm{A}^{23}$ in a manner similar to the uPA/uPAR system. Between them the MMPs are capable of degrading all the constituents of the ECM (table 1).

The transcription of most MMPs is regulated by a number of agents including growth factors, hormones, oncogene products, and tumour promoters. Transcription is induced by pro-angiogenic factors such as interleukin $1 \beta$ (IL-1 $\beta$ ), platelet-derived endothelial cell growth factor (PD-ECGF), epidermal growth factor (EGF), basic fibroblast growth factor (bFGF), and tumour necrosis factor-alpha $(\mathrm{TNF} \alpha)$ and is suppressed by transforming growth factor-beta (TGF- $\beta$ ). ${ }^{21}$ Regulation of MMP activity is also dependent on the activation of their secreted latent pro-enzymes. Two pathways for the in vivo activation of MMPs have been postulated. The plasmin cascade ${ }^{24}$ may activate gelatinase $\mathrm{B}$ and stromelysin-1 either via the UPAR at the cell surface or at a site distant to the place of secretion. Plasmin cleaves $84 \mathrm{~N}$-terminal amino acids from latent

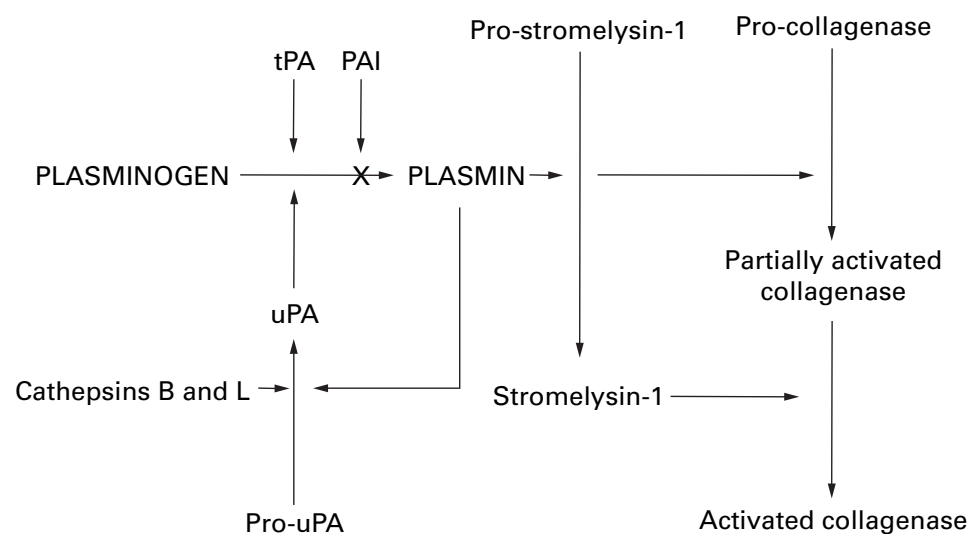

Figure 1 The plasmin cascade. $u P A=$ urokinase-type plasminogen activator; $t P A=$ tissue-type plasminogen activator; PAI = plasminogen activator inhibitor. stromelysin-1 to activate it and also 81 $\mathrm{N}$-terminal amino acids from latent interstitial collagenase to form partially active collagenase which is made fully active when stromelysin-1 cleaves a further 15 amino acids from its C-terminal (fig 1). ${ }^{25}$ On the other hand, gelatinase $\mathrm{A}$ appears to be activated by a cell mediated pattern. ${ }^{26}$ The complex nature of the ECM means that remodelling will require the combined activity of several enzymes and the co-expression of MMPs may enhance ECM degradation and therefore increase the metastatic potential.

All members of the MMP family can be regulated by their endogenous inhibitors, the TIMPs. These inhibitors are secreted by many cells in culture including fibroblasts, ${ }^{27}$ endothelial cells, ${ }^{28}$ chondrocytes, ${ }^{29}$ and vascular smooth muscle. ${ }^{30}$ The rate of ECM turnover is regulated by the balance between activated MMP levels and free TIMP levels. This balance is important in both physiological and pathological states. Four TIMPs have been characterised, the core size proteins of which are all approximately $21 \mathrm{kDa}$ and contain 12 cysteine residues. The $\mathrm{N}$-terminal is inhibitory whilst the C-terminal has the binding specificity. TIMP-1 and TIMP-2 are secreted from cells and remain soluble whereas TIMP-3 binds to the ECM with high affinity. ${ }^{31}$

TIMP-1 is a $28 \mathrm{kDa}$ protein that forms a high affinity non-covalent 1:1 complex with all active MMPs but preferentially with activated interstitial collagenase, stromelysin-1 and gelatinase A. ${ }^{32}$ TIMP-1 also forms a complex with progelatinase $\mathrm{B}$ that blocks its activation by stromelysins. ${ }^{33}$ TIMP-2 preferentially forms a 1:1 complex with gelatinase $\mathrm{A}$ and its C-terminal will strongly bind progelatinase A. ${ }^{34}$ TIMP-3 is a $24 \mathrm{kDa}$ protein with inhibitory activities against gelatinases $\mathrm{A}$ and $\mathrm{B}$, collagenase-1, and stromelysin-1, similar to the action of TIMP-1. TIMP-4 is a $23 \mathrm{kDa}$ protein $^{35}$ that can bind the C-terminal of gelatinase $\mathrm{A}$ and also progelatinase $\mathrm{A} .{ }^{36}$ The transcription of TIMPs is regulated by hormones, cytokines, anti-inflammatory agents, and tumour promoters. ${ }^{313738}$ 
Invasion, migration and metastases

Successful tumour invasion necessitates three important steps. (1) The attachment of a cell to the ECM must be weakened whilst a proteolytic defect is formed in the ECM. (2) The detached cell has to migrate through this defect. (3) Malignant cells must either have sufficient proteinase activity to break through collagenous protein barriers or acquire proteinase activity from host stromal cells. They may also benefit from proteinases derived from immune cells that infiltrate tumour tissue.

Serine proteases are capable of activating MMPs, allowing them to degrade the ECM. They also directly degrade components of the ECM. MMPs are the only known family of enzymes that can denature and digest fibrillar collagens. As the metastatic cascade requires modification of the matrix it is proposed that serine proteases and MMPs play a significant role.

Serine proteases and MMPs are frequently produced by stromal cells, possibly as a host response to the tumour. In situ hybridisation studies show higher levels of stromal MMPs close to tumour cells with lower levels further away. ${ }^{39}$ This suggests the presence of tumour cell-derived factors that are diffusible. Stromal expression of MMPs occurs particularly around tumour groups at the advancing edge of the tumour. ${ }^{40}$ As well as expression of MMPs in fibroblasts, they are also expressed in the endothelial cells of blood vessels adjacent to tumour cells. ${ }^{39}{ }^{41}$ The expression pattern of serine proteases and MMPs varies between tumours of similar and dissimilar tissue types. When found at the surface of cancer cells they may cause migration and invasion, in the vicinity of endothelial cells they may be associated with angiogenesis, and in the stroma and at the surface of fibroblasts they can lead to stromal remodelling.

The uPA system is capable of stimulating cell migration and invasion. ${ }^{42}{ }^{43} \mathrm{uPA}$, plasminogen, UPAR, and PAI-1 are all upregulated during normal cell migration with uPA and UPAR, being concentrated at the leading edge. ${ }^{44}$ The coexpression of uPA, uPAR, and PAI-1 are necessary for optimal invasion in cultured lung cancer cells ${ }^{45}$ whilst PAI- 1 has been shown to reduce tumour invasion. ${ }^{46}$ The migration of cells is decreased by PAI- 1 independent of its ability to inhibit plasminogen activation. ${ }^{47}$ UPAR expression correlates with invasive activity $^{48}$ whilst $\alpha_{2}$-antiplasmin and PAI-2 inhibit invasion. ${ }^{49} 50$

The uPA/uPAR complex is localised at adhesion sites ${ }^{51}$ where there are higher concentrations of integrins. This leads to uPAR/ vitronectin and uPAR/integrin interactions concentrated at cell:cell and cell:stroma contact sites. Proteolysis at these sites can lead to the release of cells and allow invasion. PAI-1 can inhibit migration by inhibiting proteolysis or inhibiting uPAR/vitronectin binding. PAI-1 may also be pro-migratory if it protects vitronectin from uPA destruction. PAI-1 may therefore act for or against migration and cell invasion dependent on its local expression and concentration and those of other members of the plasmin cascade. ${ }^{52}$ Additionally, uPAR is involved in chemotaxis ${ }^{53}$ and can mediate a mechanical force across the cell membrane to the cytoskeleton. ${ }^{54}$ As well as its protease activity, the uPA/uPAR complex transduces signals via intracellular tyrosine phosphorylation ${ }^{55}$ and by induction of c-fos gene expression. ${ }^{56}$ The binding of ligands to integrins leads to signal transduction ${ }^{57}$ and, as uPAR is capable of binding vitronectin and various integrins, it may initiate cell signalling and migration. The plasminogen system therefore has a major role in invasion and migration.

uPA is usually absent from resting epithelium but is upregulated by angiogenic factors such as VEGF.$^{58}$ Overexpression of uPA occurs in non-small cell lung cancer ${ }^{59}{ }^{60}$ as well as other solid tumours. ${ }^{6162} \mathrm{uPA}$ transcripts are present in a high percentage of lung cancers, principally within the stromal cells (fibroblasts, perivascular cells and inflammatory cells), but also within a smaller percentage of the cancer cells. ${ }^{63}$ uPA protein is detected mainly in the stromal cells of lung cancers. PAI- 1 is found in endothelial cells in colon carcinoma ${ }^{64}$ and the endothelial and cancer cells in breast tumours. ${ }^{65}$

There is considerable evidence to suggest that MMPs are actively involved in the metastatic process. MMP concentrations relate to metastatic potential in vitro ${ }^{66}$ whilst synthetic MMP inhibitors like batimastat decrease the spread of cancer in vivo. ${ }^{67}$ Transfection with cDNA for gelatinase A, gelatinase $\mathrm{B}$, and MT1-MMP also increases metastasis in various cancer cell lines. ${ }^{2668}$ Overexpression of TIMP-1 and TIMP-2 leads to decreased angiogenesis, endothelial cell migration and invasion $^{69-71}$ and antisense downregulation of TIMP-1 mRNA increases invasion. ${ }^{72}$

High levels of MMP expression are found in non-small cell carcinoma ${ }^{73-78}$ and in many malignant tissue types including breast, ${ }^{79}$ ovarian, ${ }^{80}$ prostatic, $^{81}$ gastric, ${ }^{82}$ colonic, ${ }^{83}$ thyroid, ${ }^{80}$ and squamous cell carcinomas of the head and neck. ${ }^{73}$ No single MMP is overexpressed in all tumour cells nor consistently overexpressed in every tumour of a single histological classification. The number of MMP family members detected tends to increase with increased tumour stage and the levels of any individual MMP tends to be higher the more advanced the tumour stage. Stromal expression of MMPs and serum proteases predominates over the cancer cell expression in a pattern seen with many types of cancer. ${ }^{79} 84$ This suggests a supportive or pro-active role for the stroma in cancer, probably as a host response to the tumour.

The ratio of active gelatinase A to latent progelatinase $\mathrm{A}$ increases as the tumour grade increases in breast cancer. ${ }^{85}$ The activation rate of progelatinase A is significantly higher in advanced breast cancer with lymph node spread. ${ }^{86}$ The presence of progelatinase A may mark the malignant potential of a cell. Experiments in human lung carcinoma cell lines show an infiltrating capacity that correlates with a high expression of gelatinase A mRNA. ${ }^{87}$ Increasing levels of gelatinase $\mathrm{A}$ are found as 
lesions progress from dysplasia through carcinoma in situ to frankly invasive carcinoma of breast and prostate. ${ }^{48}$ Although gelatinase $\mathrm{A}$ is the most commonly expressed MMP in non-small cell lung cancer, further studies are required to see if levels of gelatinase A expression increase as dysplasia changes to carcinoma. Gelatinase A is mainly expressed in stromal cells closest to cancer cells but also some tumour cells in the peripheral regions of cancer colonies. ${ }^{89}$ No difference has been found in the levels of gelatinase A and the histological subtype, but the level of gelatinase A is associated with the invasive behaviour and metastatic potential of most histological types of lung neoplasm. ${ }^{76}$

The expression of gelatinase A can frequently be superimposed on to that of MT1-MMP. ${ }^{75}$ This suggests that the transcription of these two genes may be coordinated and that MT1-MMP then activates progelatinase A allowing ECM degradation. No association between gelatinase A and MT1-MMP in normal lung parenchyma has been found. ${ }^{89}$ The correlation of MT1-MMP with gelatinase A activation in pulmonary carcinomas again suggests that MT1-MMP is a tumour specific activator of progelatinase $\mathrm{A}^{78} \mathrm{MT} 1-\mathrm{MMP}$ mRNA and its protein are present in the stroma of adenocarcinoma and both the stroma and tumour cells of squamous cell cancer. ${ }^{8790}$ Activation of gelatinase $\mathrm{A}$ involves binding of a progelatinase A/TIMP-2 complex to a cell surface receptor followed by cleavage by MT1-MMP. This restricts gelatinase A activity to the pericellular region such as the invasive edge of a tumour. ${ }^{26}$ The integrin $\alpha v \beta 3$ acts as a receptor for vitronectin and is capable of binding gelatinase $\mathrm{A} \cdot{ }^{91} \alpha \mathrm{v} \beta 3$ is involved in the induction of gelatinase A and TIMP-2 expression in melanoma cell lines. ${ }^{92}$ This allows gelatinase A activity to be directed towards the pericellular space around invasive cells, ${ }^{91}$ thereby facilitating tumour cell migration and invasion. This may well occur in other solid tumour types.

There are several matrix proteins that can stimulate chemotaxis and haptotaxis (attraction to a bound substrate) including laminin, fibronectin, vitronectin, type I and IV collagen, ${ }^{93}$ and thrombospondin. ${ }^{94}$ This couples the process of ECM degradation by proteases to cell motility. Tumour cells adhere to the ECM and migrate via integrin receptors. ${ }^{95}$ The breast epithelial basement membrane is made up of laminin-1 and 5 and collagen IV. Laminin-5 is expressed at the invasive edge of breast and colon cancers. ${ }^{88}$ The addition of gelatinase A to breast epithelial cells grown on wells coated with laminin-5 leads to migration without a change in cell adhesion, unlike wells coated with collagen IV, laminin-1, or fibronectin. ${ }^{96}$ The addition of batimastat, a synthetic MMP inhibitor, prevents the migration initiated by gelatinase $\mathrm{A}$ whilst the addition of gelatinase B or plasmin has no effect on breast epithelial cell migration. Laminin-5 is a target for proteolysis by gelatinase A and gelatinase A can provide a signal for cells to initiate migration. Whether a similar signal caused by gelatinase A occurs in lung cancer has not been elucidated.

Gelatinase B expression is strongly associated with the metastatic ability of rat embryo fibroblasts, overexpression leading to increased metastatic potential after injection into nude mice. ${ }^{97}{ }^{98}$ Gelatinase $\mathrm{B}$ mRNA is present in the stroma closely surrounding tumour cell clusters in non-small cell lung cancer ${ }^{87}$ and in the tumour cells of squamous cell carcinoma ${ }^{99}$ and adenocarcinoma.$^{75}$ Increasing immunolocalisation of gelatinase A and B are found as colonic tubular-adenomas progress to adenocarcinomas. ${ }^{83}$

Collagenase-1 and stromelysin-1 and stromelysin-3 have been identified in nonsmall cell lung cancer ${ }^{75} 77$ but not in nonneoplastic lung. Stromelysin-1 transcripts are detected especially in squamous cell lung carcinoma, again more commonly in fibroblasts. ${ }^{75}$ Stromelysin-3 has been described in bronchial epithelial cells in in vitro and ex vivo wound repair models. ${ }^{100}$ It is expressed in bronchial dysplasia and in in situ carcinomas which have an increased likelihood of developing invasive squamous cell carcinoma. ${ }^{101}$ This suggests that induction of stromelysin-3 in fibroblasts may be an early event in malignant transformation. Stromelysin-3 and uPA are frequently co-expressed, ${ }^{77}$ suggesting cooperation in ECM breakdown with stromelysin-3 degrading $\alpha_{1}$-antitrypsin allowing uPA and the other serum proteases to degrade the matrix.

Matrilysin differs from the other MMPs because its expression is in epithelial rather than mesenchymal-derived cells. Matrilysin has been found in both benign and malignant stages of many adenocarcinomas with increased levels in the malignant tissue. ${ }^{40} 102$ Enhancement of matrilysin expression in tumour cell lines increases invasive potential and tumorigenesis when inoculated into immunosuppressed host animals, ${ }^{103}$ and there is a significant reduction in the number and size of intestinal adenomas in matrilysin-null mice compared with controls. ${ }^{104}$ This may suggest that matrilysin is responsible for the aggressive behaviour of tumours, especially in the early stage. Matrilysin is expressed frequently in non-small cell lung cancer, mainly in the cytoplasm of cancer cells but also in fibroblasts. ${ }^{77}$ High levels of matrilysin mRNA are found in squamous and adenocarcinoma whilst low levels are found in non-neoplastic lung tissue. ${ }^{73}$ One report favours expression in adenocarcinoma over squamous cells. ${ }^{74}$ Matrilysin positive tumour cells are more common in the peripheral areas of the tumour than in the centre, suggesting a possible role in tumour cell invasion of the ECM and angiogenesis.

Not surprisingly, low TIMP expression correlates with increased invasiveness in various murine and human cell lines ${ }^{37} 105$ but not all malignancies have raised MMP activity with decreased TIMP activity. In several reports raised levels of TIMPs have been found in malignant tissue. ${ }^{73} 106107$ TIMP-1 expression is associated with the progression of colorectal tumours from adenoma to invasive adenocarcinoma. ${ }^{73} 107$ Rat embryo fibroblasts 
transfected to overexpress TIMP-2 have a reduced in vivo growth rate and decreased local invasion after subcutaneous injection into nude mice. They also show decreased lung colonisation when injected intravenously. ${ }^{71}{ }^{108}$ Spontaneous loss of the metastatic phenotype in a human epidermoid carcinoma line is accompanied by an increase in TIMP-2 expression. ${ }^{105}$

TIMP-1, TIMP-2 and TIMP-3 are present in both tumour and non-neoplastic lung. The frequency of TIMP-1 and TIMP-2 expression is significantly higher in non-neoplastic lung whereas TIMP-3 expression tends to increase with malignancy. ${ }^{89}$ TIMP-1 and TIMP-2 mRNA is found mainly in the stroma surrounding tumour cells, especially in well differentiated tumours. TIMP-3 occurs primarily in stromal cells and occasionally in adenocarcinoma cells. The maximal expression of TIMP-3 in colorectal adenocarcinomas occurs in the stroma associated with the invasive edge of moderately and poorly differentiated tumours. ${ }^{109}$ This pattern of expression is interesting as TIMP-3 has been shown to be anti-angiogenic. ${ }^{110}$

\section{Growth}

Plasmin and uPA are involved in the activation of specific growth factors including $b F G F,{ }^{111}$ hepatocyte growth factor, ${ }^{112}$ and TGF- $\beta .{ }^{113}$ TGF- $\beta$ activation increases expression of PAIs ${ }^{113}$ resulting in a negative feedback loop.

The classical view of MMPs and their involvement in malignancy is their role in intravasation and extravasation via their proteolytic effect on physical barriers. Mounting evidence shows that MMPs can induce growth and tumorigenicity in various cell types. Transfection of cDNA for matrilysin into colonic carcinoma cells increases tumorigenicity with little change in invasion. ${ }^{114} \mathrm{~A}$ reduction of TIMP-1 can increase metastasis and tumorigenicity $^{72}$ whilst transfection of melanoma cells with TIMP-2 cDNA decreases growth and metastasis. ${ }^{71}$ In vivo observation of early metastasis by intravital videomicroscopy suggests that the rate limiting step of metastasis is the growth of newly extravasated cells. The ability of breast cancer cells of low and high metastatic potential to extravasate has been shown to be equal. ${ }^{115}$ Overexpression of TIMP-1 showed no effect on extravasation but did decrease the rate of growth after extravasation. ${ }^{116}$ These cells also demonstrated poor adhesive contacts to vessels and between themselves. MMPs may contribute to the initiation of growth at both the primary and secondary site by altering the local environment - for example, allowing the access of growth factors into the ECM.

Over expression of TIMP-1, TIMP-2, and TIMP-4 can inhibit tumour growth in vitro and in vivo which would be expected from their ability to inhibit MMPs. ${ }^{17-119}$ TIMP-1 and TIMP-2 can also stimulate growth and proliferation in a variety of cells. ${ }^{120-122}$ TIMP-1 potentiates erythroid tissue ${ }^{123}$ and increases fibroblast collagenase production. ${ }^{124}$ The growth stimulating effects of TIMPs may be cell type specific, reliant on an appropriate receptor for the TIMP-growth factor domain or dependent on the respective TIMP:MMP concentrations.

\section{Apoptosis}

Apoptosis (programmed cell death) is suppressed in the presence of an intact ECM basement membrane. ${ }^{125}$ Increased stromelysin-1 expression leads to apoptosis and this can be blocked by MMP inhibition. ${ }^{125}$ MMPs may therefore be involved in apoptosis by their ability to degrade the ECM. p53 is a promoter of apoptosis, a regulator of the cell cycle, and a tumour suppressor gene. The promoter region for the gene encoding gelatinase A contains a p53 binding site and is subject to regulation by wild-type but not mutant p53 in vivo and in vitro. ${ }^{126}$ In the absence of the p53 binding site, p53 leads to repression of the gelatinase A promoter. This links p53, MMPs, and apoptosis. Perhaps in carcinogenesis mutant p53 has no regulatory control over gelatinase $\mathrm{A}$.

Adenovirus mediated transfer of TIMP-1, TIMP-2, and TIMP-3 genes leads to overproduction of their corresponding proteins and to inhibition of melanoma cell invasion. ${ }^{127}$ TIMP-1 and TIMP-2 act solely by MMP inhibition, whilst the effect of TIMP-3 is more potent. At 24 hours raised TIMP-3 expression leads to a marked decrease in invasion and cell adhesion. At 72 hours there is an increase in apoptosis and a decrease in viable cells. ${ }^{127} \mathrm{An}$ increase in programmed cell death by TIMP-3 also occurs in vascular smooth muscle ${ }^{128}$ and in colon carcinoma cells. ${ }^{129}{ }^{130}$ This may be due in part to stabilisation of $\mathrm{TNF}-\alpha$ receptors on the cell surface. Apoptosis was neither caused by TIMP-1 or TIMP-2 nor by synthetic MMP inhibition, which indicates that MMP inhibition alone does not lead to apoptosis. It appears that loss of cell adhesion to the ECM may be the important factor. Recent evidence shows that overexpression of TIMP-2 leads to decreased apoptosis but increased necrosis, which suggests that it too plays a part in tumour cell survival. ${ }^{69}$

PAI-2 is found in both cytosolic and secreted forms. The cytosolic form of PAI-2 is probably involved in apoptosis independent of its ability to inhibit uPA. PAI-2 is similar in form to CrmA (a viral serpin) ${ }^{131}$ and CrmA can inhibit interleukin-1 $\beta$ converting enzyme (ICE), a potent inducer of apoptosis. ${ }^{131}$ This finding suggests that PAI-2 may inhibit apoptosis. The balance between proliferation and apoptosis defines whether a tumour grows or remains dormant. If the major role of PAI-2 is to inhibit apoptosis, its expression in a tumour would tip the balance in favour of proliferation and tumour growth. The addition of recombinant PAI-2 leads to a decrease in growth of uPA producing tumours in SCID mice. ${ }^{132}$ Melanoma cell lines overexpressing PAI-2 injected into SCID mice develop fewer metastases than PAI-2 negative controls. ${ }^{133}$ In these studies inhibition of the plasmin cascade and invasion appears more important than the ability to inhibit apoptosis. 


\section{Angiogenesis}

The process of angiogenesis has three steps that are similar to those involved in invasion: proliferation of endothelial cells, the breakdown of the ECM, and endothelial cell migration. The level of angiogenesis is a well recognised prognostic indicator in many tumour types ${ }^{134}$ including non-small cell lung carcinoma. ${ }^{135}$ The quantity of vessels increases as bronchial epithelium progresses from normal tissue through to carcinoma in situ. ${ }^{136}$ The association between angiogenesis and growth factors in non-small cell lung cancer has been studied demonstrating relationships with VEGF, ${ }^{137} \mathrm{bFGF}^{138}$ and PD-ECGF. ${ }^{139}$ This correlates with the pro-angiogenic properties of these growth factors. A strong inverse relationship between bcl-2 and angiogenesis has also been found. ${ }^{140}$ As normal lung epithelium expresses bcl-2, this suggests that loss of bcl-2 activity may allow angiogenesis to occur.

It is logical that proteases play an important role in angiogenesis. The levels of uPA in breast cancer correlate with vascular grade ${ }^{141}$ and this will probably be the case in non-small cell lung cancer. The expression of gelatinase $\mathrm{A}$ and $\mathrm{B}$ in endothelial cells is also important in angiogenesis. ${ }^{142}$ Gene targeting has led to the development of gelatinase A-deficient mice that develop normally. ${ }^{143}$ Gelatinase A-deficient mice show decreased angiogenesis compared with normal mice when injected with B16-BL6 melanoma cells and a slower growth and decreased colonies in those injected with Lewis lung carcinoma cells. ${ }^{144} \mathrm{~B} 16-$ BL6 melanoma cells do not express gelatinase $\mathrm{A}$ in vitro $^{145}$ so the presence of gelatinase A activity in these tumours in the normal mice but not in the gelatinase A-deficient mice suggests that this has derived from the host tissue. Lewis lung carcinoma cells can produce gelatinase $\mathrm{A}$ yet they still demonstrate poorer growth in the gelatinase A-deficient mice. Host produced gelatinase A must therefore play a critical role in tumour invasion and angiogenesis. As there is only partial suppression of angiogenesis in gelatinase A-deficient mice, presumably the other proteases partly compensate for the lack of this MMP. Gelatinase A leads to endothelial cell tube formation on matrigel and this is blocked by TIMP-1 and TIMP-2, ${ }^{146}$ yet TIMP-1 is capable of promoting endothelial cell proliferation. ${ }^{147}$ Angiogenesis is decreased by the TIMP-2 inhibition of MMPs ${ }^{148}$ and UPAR antagonists are also capable of decreasing angiogenesis. ${ }^{149}$

A major event in angiogenesis is stimulation of ECM modelling. bFGF released into the $\mathrm{ECM}$ is often bound to the heparan sulphate proteoglycans on laminin, fibronectin, and collagen. ${ }^{150}$ ECM damage or proteolysis will therefore release $\mathrm{bFGF}$ which is proangiogenic and upregulates uPA, PAI-1, and gelatinase expression ${ }^{151}$ and represses TIMP-2 expression. ${ }^{148}$ This may be important in physiological wound healing and in tumours with raised MMP levels.

MMPs also process precursors into bioactive forms. Gelatinase A (but not gelatinase B) is capable of cleaving the ectodomain of fibro- blast growth factor receptor 1 (FGFR-1) and therefore of modulating the angiogenic activity of bFGF. ${ }^{152}$ MMPs also act on TNF- $\alpha$ and its receptor. ${ }^{153}{ }^{154}$ VEGF induces the expression of interstitial collagenase at the exclusion of other $\mathrm{MMPs}^{155}$ and interstitial collagenase is an absolute requirement for angiogenesis. ${ }^{156}$ The addition of VEGF to dermal microvascular endothelial cells increases gelatinase A levels and decreases gelatinase $\mathrm{A}$ inhibition by decreasing TIMP-2 levels. ${ }^{157}$ Although interstitial collagenase levels remained unchanged, there was decreased inhibition as TIMP-1 levels were reduced. These changes in respective levels of MMPs and their inhibitors could contribute to the role played by VEGF in angiogenesis.

MMPs are traditionally thought to be pro-angiogenic whilst TIMPs are antagonistic. There is evidence that the plasmin cascade and MMP activity may also have an anti-angiogenic component. Gelatinase B, matrilysin, and a macrophage metalloelastase hydrolyse plasminogen to angiostatin, a potent inhibitor of angiogenesis. ${ }^{158}{ }^{159}$ Endostatin is a similar antiangiogenic substance formed by collagen type XVIII proteolysis. ${ }^{160}$ Kringle 5 of human plasminogen also selectively inhibits endothelial migration. ${ }^{161}$ These anti-angiogenic breakdown products may serve as a negative feedback loop. Angiostatin can be produced by the primary tumour and must pass through the circulation as it can be isolated from urine. ${ }^{162}$ Excision of the primary tumour can remove this inhibitory effect and lead to rapid growth of previously dormant metastases which is a well recognised observation.

The fumagillin analogue TNP-470 inhibits the proliferation of growth factor stimulated endothelial cells ${ }^{163}$ and inhibits bFGF induced tubule formation. Lung metastases in mice remain dormant under suppression of angiogenesis by TNP-470. Removal of suppression leads to rapid growth of the micrometastases. Interestingly, whilst the rate of proliferation of cells is equal in dormant and growing metastases, the rate of apoptosis in dormant metastases is three times that of growing metastases. ${ }^{164}$ This suggests that inhibitors of angiogenesis may control the growth of metastases by indirectly increasing apoptosis, presumably by starving the tumour of nutrients and oxygen.

\section{Prognosis}

The best predictor for outcome in non-small cell lung cancer is the International Staging System. ${ }^{165}$ Subjects with the same stage of disease can have markedly different rates of disease progression. This finding suggests that these tumours, despite having the same histological subtype, are biologically different. Immunohistochemical investigation may reveal other prognostic markers and may suggest subgroups that could benefit from adjuvant therapy after surgical resection.

Raised levels of uPA have been found in many malignant tissue types and this confers a poor prognostic significance in breast, ${ }^{166} 167$ bladder, ${ }^{168}$ gastric, ${ }^{169}$ colonic, ${ }^{170}$ cervical, ${ }^{171}$ 
ovarian, ${ }^{172}$ and renal carcinoma ${ }^{173}$ and also a poor prognosis in node negative breast cancer. ${ }^{174}{ }^{175}$ Increased levels of uPA expression in stromal cells correlate with increased tumour size, lymph node secondaries, and advanced tumour stage in non-small cell lung cancer. ${ }^{59}$ Immunohistochemical studies have shown that uPA in non-small cell lung cancer is associated with a poor prognosis ${ }^{176}$ but ELISA studies have not shown a prognostic role for uPA. ${ }^{177}$ The presence of uPAR correlates with decreased survival in squamous cell carcinoma. ${ }^{178}$ uPAR is also associated with a poor prognosis in colon ${ }^{179}$ and breast cancer. ${ }^{180}$

Raised PAI-1 expression is associated with a poor outcome in lung adenocarcinoma. ${ }^{177}$ Raised levels of PAI-1 suggest a more aggressive phenotype and give a poor prognosis in breast, ${ }^{175} 181$ gastric, ${ }^{169}$ and ovarian carcinoma. ${ }^{172}$ Raised levels of PAI-2 are found in lung cancer with lower levels being present in the lymph nodes of metastatic disease. ${ }^{178}$ Low PAI-2 levels correlate with dissemination in non-small cell lung cancer ${ }^{182}$ and this agrees with the finding that PAI-2 is associated with a good prognosis in most tissue types. ${ }^{183-185}$ However, the relationship between PAI-2 and outcome remains unclear. In one study of colonic carcinoma high levels of PAI-2 were associated with a more aggressive disease. ${ }^{170}$ This anomaly may be related to the relative concentrations of PAIs and proteases in these tumours and the putative ability of PAI-2 to inhibit apoptosis.

Significantly higher mRNA levels of both gelatinase $\mathrm{A}$ and gelatinase $\mathrm{B}$ are found in stage III non-small cell lung cancer than in stages I and II, with no difference in histological subtype. ${ }^{76}$ This association with tumour grade also occurs in breast ${ }^{186}$ and colorectal tumours. ${ }^{83}$ MT1-MMP is expressed significantly more frequently in stage III non-small cell lung cancer than in stages I and II and increased MT1-MMP mRNA correlates with the presence of lymph node secondaries in lung tumours. ${ }^{78}$ Higher numbers of stromelysin-3 positive fibroblasts and the co-expression of stromelysin-1, stromelysin-3, and uPA correlate with increased tumour size and with lymph node spread. ${ }^{77}$

TIMP-3 is more frequently expressed in stage III non-small cell lung cancer, along with many MMPs, ${ }^{89} 109$ whereas TIMP-1 and TIMP-2 show an early substantial (although non-significant) decline as the tumour stage increases. $^{89}$ The decrease in TIMP-1 and TIMP-2 as the stage progresses gives support to the theory that the metastatic potential is dependent on the balance between MMP and TIMP activity. This is at odds with other studies showing that a high TIMP-1 expression is associated with a poor prognosis in non-small cell lung cancer, ${ }^{187}$ and that increased stromelysin-3 and TIMP-2 expression occurs in poorly differentiated squamous cell carcinoma and in those with nodal metastases. ${ }^{188}$ In both breast and bladder cancer raised TIMP-1 mRNA and TIMP-2 protein are associated with a poor prognosis. ${ }^{189} 190$ There is raised TIMP-1 expression in colorectal cancers with secondary spread ${ }^{191}$ and TIMP-1 expression correlates with the more aggressive phenotype in bladder cancer. ${ }^{192}$ Raised levels of TIMPs in malignancy may occur as a response to raised levels of MMPs. The ability of TIMPs to stimulate cell proliferation may account for raised levels being present in advanced disease.

\section{Therapy}

Synthetic inhibitors of metalloproteinases have been developed and are undergoing clinical trials. Batimastat (BB94) is a hydroxamine analogue that gives widespread inhibition of MMPs. Batimastat decreases in vitro ECM degradation and invasion of endothelial cells through an artificial membrane. ${ }^{193}$ It decreases the metastatic spread of murine melanoma ${ }^{194}$ and human mammary carcinoma cells in mice. ${ }^{195}$ The effects of MMP inhibitors on growth in vivo may be related to their effects on tumour angiogenesis. MMP inhibitors block angiogenesis assayed in chick and rat models of neovascularisation. ${ }^{196} 197$ Batimastat has low oral bioavailability but has been used in clinical trials to treat malignant ascites and pleural effusions. ${ }^{198}$ Malignant pleural effusions contain high concentrations of gelatinases $\mathrm{A}$ and $\mathrm{B}^{199}$ so metalloproteinase inhibitors appear to offer a new way of approaching this common problem. Marimastat (BB-2516) is an orally active synthetic MMP inhibitor that decreases lung and mammary cancer growth in animal models. ${ }^{200}$ It has been used in phase 1, 2 and 3 studies leading to a fall in the rate of rise of tumour markers in a dose dependent manner. ${ }^{201}$ CT-1746 is a gelatinase selective MMP inhibitor that reduces tumour spread and metastasis, converting aggressive colonic cancer into a more indolent disease in a nude mice model. ${ }^{202}$ It has been used in conjunction with cyclophosphamide to inhibit the growth and metastatic spread of Lewis lung carcinoma in mice. ${ }^{203}$ Together they have a greater effect than when given separately. D-penicillamine can inhibit the activation of prometalloproteinases and offers another way of decreasing MMP activity.

Angiostatin and endostatin are capable of decreasing the growth of primary tumours and metastases in vivo. ${ }^{204} 205$ After treatment is stopped the tumours grow again but repeated therapy can lead to dormancy without the development of drug resistance.

Tumour cells and endothelial cells can stimulate the growth of each other. Combination treatment regimes with traditional cytotoxic chemotherapy and anti-angiogenic drugs could affect both of these distinct cell populations. Long term treatment with MMP inhibitors may be used in patients with low or non-existent metastatic disease. Inhibition of MMP expression by antisense techniques may also have a clinical role. The pharmaceutical use of TIMPs may not be as straightforward as they lack bioavailability and may stimulate cell growth. Trials of these agents will evaluate whether our increased knowledge of the molecular biology of malignancy can be put into clinical practice. 


\section{Conclusions}

The plasmin cascade, MMPs, and TIMPs are involved in invasion, migration, growth and angiogenesis and have a putative role in apoptosis. The prognostic significance of protease expression and association with angiogenesis (a recognised prognostic marker in its own right) ${ }^{206} 207$ needs to be evaluated further. Immunostaining of tissue from surgical resections of non-small cell lung cancer and assessing prognostic markers may highlight a subgroup of patients who could benefit from adjuvant chemotherapy or radiotherapy. The use of synthetic protease inhibitors may lead to a new approach in the management of non-small cell lung cancer, either alone or in conjunction with established cytotoxic agents. Further research into the molecular biology of lung cancer may highlight other pathways that can be manipulated for clinical gain.

1 Yurchenco PD, Cheng YS, Colognato H. Laminin forms an independent network in basement membranes. 7 Cell Biol independent network

2 Chambers AF, Matrisian LM. Changing views of the role of matrix metalloproteinases in metastasis. $\mathcal{F}$ Natl Cancer Inst 1997;89:1260-70.

3 Barsky SH, Siegal GP, Jannotta F, et al. Loss of basement membrane components by invasive tumours but not by their benign counterparts. Lab Invest 1983;49:140-7.

4 Liotta LA, Rao N, Barsky SH. Tumour invasion and the extracellular matrix. Lab Invest 1983;49:636-49.

5 Ray JM, Stetler-Stevenson WG. The role of matrix metalloproteinases and their inhibitors in tumour invasion, metastasis and angiogenesis. Eur Respir f 1994;7:2062-72.

6 Besser D, Verde P, Nagamine Y, et al. Signal transduction and the u-PA/uPAR system. Fibrinolysis 1996;10:215-37.

7 Dano K, Andreasen PA, Grondahl-Hansen K, et al. Dano K, Andreasen PA, Grondahl-Hansen K, et al.
Plasminogen activators tissue degradation and cancer. $A d v$ Plasminogen activators tissue

8 Ichinose A, Fujikawa K, Suyama T. The activation of pro-urokinase by plasma kallikrein and its inactivation by thrombin. F Biol Chem 1986;261:3486-9.

9 Kobayashi H, Schmitt M, Goretzki L, et al. Cathepsin B efficiently activates the soluble and the tumour cell receptor-bound form of the proenzyme urokinase-type plasminogen activator (pro-uPA). F Biol Chem 1991;266 5147-52.

10 Goretzki L, Schmitt M, Mann K, et al. Effective activation of the pro-enzyme form of the urokinase-type plasminogen activator (pro-uPA) by the cysteine protease cathepsin L. FEBS Lett 1992;297:112-8

11 Yoshida E, Ohmura S, Sugiki M, et al. Prostate-specific antigen activates single-chain urokinase-type plasminogen acti-
vator. Int $\mathcal{f}$ Cancer 1995;63:683-5.

12 Stoppelli MP, Tacchetti C, Cubellis MV, et al. Autocrine saturation of pro-urokinase receptors on human A431 saturation of pro-urokinase
cells. Cell 1986;45:675-84.

13 Mignatti P, Rifkin DB. Biology and biochemistry of proteinases in tumour invasion. Physiol Rev 1993;73:161-95.

14 Plow EF, Miles LA. Plasminogen receptors in the mediation of pericellular proteolysis. Cell Differentiation Develop 1990; 32:293-8.

15 Potempa J, Korzus E, Travis J. The serpin superfamily of proteinase inhibitors: structure, function and regulation. $\mathcal{f}$ Biol Chem 1994;269:15957-60.

16 Cubellis MV, Andreasen PA, Ragno PA, et al. Accessibility of receptor-bound urokinase to type-1 plasminogen activator inhibitor. Proc Natl Acad Sci 1989;86:4828-32.

17 Ellis V, Wun T-C, Behrendt N, et al. Inhibition of receptorbound urokinase by plasminogen activator inhibitor. $\mathcal{f}$ Biol Chem 1990;265:9904-8.

18 Laug WE, Cao XR, Yu YB, et al. Inhibition of invasion of HT-1080 sarcoma cells expressing recombinant plasminoHT-1080 sarcoma cells expressing recombinant plasm
gen activator inhibitor 2. Cancer Res 1993;53:6051-7.

19 Jensen PH, Christensen EI, Ebbesen P, et al. Lyposomal degradation of receptor-bound urokinase-type plasminogen activator is enhanced by its inhibitors in human trophoblastic choriocarcinoma cells. Cell Regul 1990;1: 1043-56.

20 Nykjaer A, Petersen CM, Moller B, et al. Purified $\alpha_{2}$-macroglobulin receptor/LDL receptor-related protein binds urokinase-plasminogen activator inhibitor type-1 complex. Evidence that the $\alpha_{2}$-macroglobulin receptor mediates cellular degradation of urokinase receptor bound complexes. F Biol Chem 1992;267:14543-6.

21 Birkedal-Hansen H, Moore WG, Bodden MK, et al. Matrix metalloproteinases: a review. Crit Rev Oral Biol Med 1993; 4:197-250.

22 Van Wart H, Birkedal-Hansen $H$. The cysteine switch: a principal regulation of metalloproteinase activity with potential applicability to the entire matrix metalloprotein-
ase gene family. Proc Natl Acad Sci USA 1990;87:5578-82.
$23 \mathrm{He}$ C, Wilhelm SM, Pentland AP, et al. Tissue co-operation in a proteolytic cascade activating human interstitial collain a proteolytic cascade activating human in
genase. Proc Natl Acad Sci 1989;86:2632-6.

24 Kleiner DJ, Stetler-Stevenson WG. Structural biochemistry and activation of matrix metalloproteinases. Curr Opin Cell Biol 1993;5:891-7.

25 Brown PD, Kleiner DE, Unsworth EJ, et al. Cellular activation of the $72 \mathrm{kDa}$ type IV procollagenase/TIMP-2 complex. Kidney Int 1993;43:163-70.

26 Sato H, Takino T, Okada Y, et al. A matrix metalloproteinase expressed on the surface of invasive tumour cells. Nature 1994;370:61-5.

27 Stricklin GP, Welgus HG. Human skin fibroblast collagenase inhibitor. Purification and biochemical characterization. f Biol Chem 1983;258:12252-8.

28 Herron GS, Banda MJ, Clark EJ, et al. Secretion of metalloproteinases by stimulated capillary endothelial cells. F Biol Chem 1986;261:2814-8.

29 Gavrilovic J, Hembry RM, Reynolds JJ, et al. Tissue inhibitor of metalloproteinases (TIMP) regulates extracellular type 1 collagen degradation by chondrocytes and endothelial cells. F Cell Sci 1987;87:357-62.

30 DeClerck YA. Purification and characterization of a collagenase inhibitor produced by bovine vascular smooth muscle cells. Arch Biochem Biophys 1988;265:28-37.

31 Leco KJ, Khokha R, Pavloff N, et al. Tissue inhibitor of metalloproteinases-3 (TIMP-3) is an extracellular matrix associated protein with a distinctive pattern of expression in mouse cells and tissues. F Biol Chem 1994;269:9352-60.

32 Apte SS, Olsen BR, Murphy G. The gene structure of tissue inhibitor of metalloproteinase (TIMP)-3 and its inhibitory activities define the distinct TIMP gene family. $\mathcal{F}$ Biol Chem 1995;270:14313-8.

33 Goldberg GI, Strongin A, Collie IE, et al. Interaction of 92-kDa type IV collagenases with the tissue inhibitor of metalloproteinases prevents dimerization, complex formation with interstitial collagenase, and activation of the proenzyme by stromelysin. $\mathscr{F}$ Biol Chem 1992;267:4583-91.

34 Howard EW, Bullen EC, Banda MJ. Preferential inhibition of 72 and $92 \mathrm{kDa}$ gelatinases by tissue inhibitor of of 72 and $92 \mathrm{kDa}$ gelatinases by tissue inhibitor
metalloproteinases-2. F Biol Chem 1991;266:13070-5.

35 Leco KJ, Apte SS, Taniguchi GT, et al. Murine tissue inhibitor of metalloproteinases-4 (TIMP-4): cDNA isolation and expression in adult mouse tissues. FEBS Lett 1997;401: 213-7.

36 Bigg HF, Shi YE, Liu YE, et al. Specific, high affinity binding of tissue inhibitor of metalloproteinases-4 (TIMP-4) to the COOH-terminal hemopexin-like domain of human gelatinase A. TIMP-4 binds progelatinase A and the $\mathrm{COOH}$-terminal domain in a similar manner to TIMP-2.f Biol Chem 1997;272:15496-500.

37 Khokha $\mathrm{P}$, Waterhouse $\mathrm{P}$, Yagel $\mathrm{S}$, et al. Antisense RNA-induced reduction in metalloproteinase inhibitor causes mouse 3T3 cells to become tumorigenic. Science 1989;243:947-50.

38 Mann JS, Kindy MS, Edwards DR, et al. Hormonal regulation of matrix metalloproteinase inhibitors in rat granulosa cells and ovaries. Endocrinology 1991;128:1825-32.

39 Pyke C, Ralfkaier E, Tryggvason K, et al. Messenger RNA for two type IV collagenases is located in stromal cells in human colon cancer. Am f Pathol 1993;142:359-65.

40 Heppner KJ, Matrisian LM, Jensen RA, et al. Expression of most matrix metalloproteinase family members in breast cancer represents a tumour induced host response. $\mathrm{Am} \mathcal{F}$ Pathol 1996;149:273-82.

41 Autio Harmainen H, Kartunnen T, Hurskainen T, et al. Expression of 72 kilodalton type IV collagenase (gelatinase
A) in benign and malignant ovarian tumours. Lab Invest 1993;69:312-21.

42 Odekon LE, Sato Y, Rifkin DB. Urokinase-type plasminogen activator mediates basic growth factor-induced bovine endothelial cell migration independent of its proteolytic activity. F Cell Physiol 1992;150:258-63.

43 Binder BR. Influence of urokinase on cell proliferation and invasion. Blood Coagul Fibrinolysis 1990;1:717-20.

44 Pepper MS, Matsumoto K, Nakamura T, et al. Upregulation of urokinase receptor expression on migratory endothelial cells. F Cell Biol 1993;122:673-84.

45 Liu G, Shuma MA, Cohen RL. Coexpression of urokinase, urokinase receptor and PAI-1 is necessary for optimum invasiveness of cultured lung cancer cells. Int $\mathcal{F}$ Cancer 1995;60:501-6.

46 Kobayashi H, Gotoh J, Fujie M, et al. Inhibition of metastasis of Lewis lung carcinoma by a synthetic peptide within growth factor-like domain of urokinase in the experimental and spontaneous metastasis model. Int $\mathcal{f}$ Cancer 1994;57: $727-33$

47 Kjoller L, Kanse S, Kirkegaard T, et al. Plasminogen activator inhibitor-1 represses integrin- and vitronectin-mediated cell migration independently of its function as an inhibitor of plasminogen activation. Exp Cell Res 1997;232:420-9.

48 Schlechte W, Brattain M, Boyd D. Invasion of extracellular matrix by cultured colon cancer cells: dependence on urokinase receptor display. Cancer Comm 1990;2:173-9.

49 Meissauer A, Kramer MD, Hofmann M, et al. Urokinasetype and tissue-type plasminogen activators are essential for the in vitro invasion of human melanoma cells. Exp Cell Res 1991;192:453-9.

50 Stahl A, Mueller BM. Binding of urokinase to its receptor promotes migration and invasion of human melanoma cells promotes migration and invasion of hitro. Cancer Res 1994;54:3066-71.

51 Glass WF, Radnik RA, Garoni JA, et al. Urokinasedependent adhesion loss and shape change after cyclic 
adenosine monophosphate elevation in cultured rat mesangial cells. F Clin Invest 1988:82:1992-2000.

52 Andreasen PA, Kjoller L, Christensen L, et al. The urokinase-type plasminogen activator system in cancer metastasis: a review. Int F Cancer 1997;72:1-22.

53 Gyetko MR, Todd RF, Wilkinson CC, et al. The urokinase receptor is required for human monocyte chemotaxis in vitro. F Clin Invest 1994;93:1380-7.

54 Wang N, Planus E, Pouchelet M, et al. Urokinase receptor mediates mechanical force across cell surface. Am f Physiol 1995;C1062-6.

55 Dumler I, Petri T, Schleuning W-D. Interaction of urokinase-type plasminogen activator (u-PA) with its cellular receptor (u-PAR) induces phosphorylation on tyrosine of a $38 \mathrm{kDa}$ protein. FEBS Lett 1993;322:37-40.

56 Dumler I, Petri T, Schleuning W-D. Induction of the c-fos gene expression by urokinase-type plasminogen activator in human ovarian cancer cells. FEBS Lett 1994;343:103-6.

57 Clark EA, Brugge JS. Integrins and signal transduction pathways. Science 1995;268:233-9.

58 Pepper MS, Ferrara N, Orci L, et al. Vascular endothelial growth factor (VEGF) induces plasminogen activators and plasminogen activator inhibitor-1 in microvascular endothelial cells. Biochem Biophys Res Commun 1991;181: $902-6$.

59 Sappino AP, Busso N, Belin D, et al. Increase of urokinasetype plasminogen activator gene expression in human lung and breast carcinomas. Cancer Res 1987;47:4043-6.

60 Ornstein DL, Zacharski LR, Memoli VA, et al. Coexisting macrophage-associated fibrin formation and tumor cell urokinase in squamous cell and adenocarcinoma of the lung tissues. Cancer 1991;68:1061-7.

61 Christensen L, Wiborg Simonsen AC, Heegaard CW, et al. Immunohistochemical staining of urokinase-type plasminogen activator, type-1 plasminogen activator inhibitor, urokinase receptor, and $\alpha_{2}$-macroglobulin receptor in human breast carcinomas. Int $\mathcal{F}$ Cancer 1996;66:441-52.

62 Buo L, Lyberg T, Jorgensen L, Johansen HT, et al. Location of plasminogen activator (PA) and PA inhibitor in human Scand 1993;101:235-41.

63 Bolon I, Gouyer V, Devouassoux M, et al. Expression of c-ets-1, collagenase-1 and urokinase-type plasminogen activator gen

64 Pyke C, Ralfkiaer E, Ronne E, et al. Immunohistochemical detection of the receptor for urokinase plasminogen activa-
tor in human colon cancer. Histopathology 1994;24:131-8.

65 Reilly D, Christensen L, Duch M, et al. Type-1 plasminogen activator inhibitor in human breast carcinomas. Int $\mathcal{f}$ Cancer 1992;50:208-14.

66 Garbisa S, Pozatti R, Muschel R, et al. Secretion of type IV collagenolytic protease and metastatic phenotype: induction by transfection with c-Ha-ras but not with c-Ha-ras plus Ad2-E1a. Cancer Res 1987;47:1523-8.

67 Talbot DC, Brown PD. Experimental and clinical studies on the use of matrix metalloproteinase inhibitors for the treatment of cancer. Eur 7 Cancer 1996;32A:2528-33.

68 Kawamata H, Kameyama S, Kawai K, et al. Marked acceleration of the metastatic phenotype of a rat bladder carcinoma cell line by the expression of human gelatinase carcinoma cell line by the expre
A. Int $\mathcal{F}$ Cancer 1995;63:568-75.

69 Valente P, Fassina G, Melchiori A, et al. TIMP-2 overexpression reduces invasion and angiogenesis and protects $\mathrm{B} 16 \mathrm{~F} 10$ melanoma cells from apoptosis. Int $\mathcal{F}$ Cancer 1998;75:246-53.

70 Schultz RM, Silberman S, Persky B, et al. Inhibition of recombinant tissue inhibitor of metalloproteinases of human amniotic invasion and lung colonisation by murine B16-F10 melanoma cells. Cancer Res 1988;48:5539-45.

71 Montgomery AM, Mueller BM, Reisfield RA, et al. Effect of tissue inhibitor of the matrix metalloproteinases-2 expression on the growth and spontaneous metastasis of a human sion on the growth and spontaneous metastasis of
melanoma cell line. Cancer Res 1994;54:5467-73.

72 Khokha R, Denhardt DT. Matrix metalloproteinases and tissue inhibitors of metalloproteinases: a review of their role in tumorigenesis and tissue invasion. Invasion Metastasis 1989;9:391-405

73 Muller D, Breathnach R, Engelmann A, et al. Expression of collagenase-related metalloproteinase genes in human lung or head and neck tumours. Int f Cancer 1991;48:550-61.

74 Kawano N, Osawa H, Ito T, et al. Expression of gelatinase A, tissue inhibitor of metalloproteinases-2, matrilysin, and trypsin(ogen) in lung neoplasms: an histochemical study. Hum Pathol 1997;28:613-22.

75 Urbanski SJ, Edwards DR, Maitland A, et al. Expression of metalloproteinases and their inhibitors in primary pulmometalloproteinases and their inhibitors in prima

76 Brown PD, Bloxidge RE, Stuart NSA, et al. Association between expression of 72-kilodalton gelatinase and tumour spread in non-small cell lung cancer. $\mathcal{F}$ Natl Cancer Inst 1993;85:574-8

77 Bolon I, Devouassoux M, Robert C, et al. Expression of urokinase-type plasminogen activator, stromelysin-1, stromelysin-3 and matrilysin genes in lung carcinomas. An f Pathol 1997;150:1619-29.

78 Tokaraku M, Sato H, Murakami S, et al. Activation of the precursors of gelatinase $\mathrm{A} / 72 \mathrm{kDa}$ type IV collagenase/ MMP-2 in lung carcinomas correlates with the expression of membrane-type matrix metalloproteinases (MT-MMP) of membrane-type matrix metalloproteinases (MT-MMP) 9 .
79 Basset P, Bellocq JP, Wolf C, et al. A novel metalloproteinase gene specifically expressed in stromal cells of breast gene specifically expressed in strom
carcinomas. Nature 1990;348:699-704.

80 Sato H, Kida Y, Mai M, et al. Expression of genes encoding type IV collagen-degrading metalloproteinases and tissue inhibitors of metalloproteinases in various human tumor cells. Oncogene 1992;7:77-83

81 Boag AH, Young ID. Increased expression of the 72-kd type IV collagenase in prostatic adenocarcinoma. Demonstration by immunohistochemistry and in-situ hybridization. Am $\mathcal{F}$ Pathol 1994;144:585-91.

82 Nomura H, Sato H, Seiki $M$, et al. Expression of membrane-type matrix metalloproteinase in human gastric carcinomas. Cancer Res 1995;55:3263-6.

83 Tomita T, Iwata K. Matrix metalloproteinases and tissue inhibitors of metalloproteinases in colonic adenomasadenocarcinomas. Dis Colon Rectum 1996;39:1255-64.

84 Polette M, Gilbert N, Stas I, et al. Gelatinase A expression and localization in human breast cancers. An ISH study and immunohistochemical detection using confocal microscopy. Virchows Arch 1994;426:29-35.

85 Davies B, Miles DW, Happerfield MLC, et al. Activity of type IV collagenases in benign and malignant breast disease. Br f Cancer 1993;67:1126-31.

86 Iwata H, Kobayashi S, Iwase H, et al. Production of matrix metalloproteinases and tissue inhibitors of metalloproteinases in human breast carcinomas. Fap $\mathcal{F}$ Cancer Res 1996;87:602-11.

87 Collier IE, Wilhelm SM, Eisen AZ, et al. H-ras oncogenetransformed bronchial epithelial cells (TBE-1) secrete a single metalloproteinase capable of degrading basement collagen. F Biol Chem 1988;263:6579-87.

88 Monteagudo C, Merino MJ, San-Juan J, et al. Immunohistochemical distribution of type IV collagenase in normal, benign and malignant breast tissue. Am f Pathol 1990;136: 585-92.

89 Nawrocki B, Polette M, Marchand V, et al. Expression of matrix metalloproteinases and their inhibitors in human bronchopulmonary carcinomas: quantitative and morphological analyses. Int $\mathcal{F}$ Cancer 1997;72:556-64.

90 Polette M, Nawrocki B, Gilles C, et al. MT-MMP expression and localization in human lung and breast cancers. Virchows Arch 1996;428:29-35.

91 Brooks PC, Stromblad S, Sanders LC, et al. Localization of matrix metalloproteinase MMP-2 to the surface of invasive cells by interaction with integrin $\alpha v \beta 3$. Cell 1996;85:68393.

92 Bafetti LM, Young TN, Itoh Y, et al. Intact vitronectin induces matrix metalloproteinase-2 and tissue inhibitor of metalloproteinases-2 expression and enhanced cellular invasion by melanoma cells. F Biol Chem 1998;273:143-9.

93 Klominek J, Robert KH, Sundquist KG. Chemotaxis and haptotaxis of human malignant mesothelioma cells: effects of fibronectin, laminin, type IV collagen, and an autocrine motility factor-like substance. Cancer Res 1993;53:437682

94 Taraboletti G, Roberts DD, Liotta LA. Thrombospondininduced tumour cell migration: haptotaxis and chemotaxis are mediated by different molecular domains. $7 \mathrm{Cell}$ Biol 1987;105:2409-15.

95 Baker SE, Hopkinson SB, Fitchmun M. Laminin-5 and hemidesmosomes: role of the alpha 3 subunit in hemidesmosome stability and assembly. F Cell Sci 1996; 109:2509-20.

96 Gianelli G, Falk-Marzillier J, Schiraldi O, et al. Induction of cell migration by matrix metalloprotease-2 cleavage of laminin-5. Science 1997;277:225-8.

97 Bernhard EJ, Gruber SB, Muschel RJ. Direct evidence linking expression of metalloproteinase 9 (92-kDa gelatinase/ collagenase) to the metastatic phenotype in transformed rat collagenase) to the metastatic phenotype in transforn

98 Hua J, Muschel RJ. Inhibition of matrixmetalloproteinase 9 expression by a ribozyme blocks metastasis in a rat sarcoma model system. Cancer Res 1996;56:5279-84.

99 Cannette-Soler R, Litzky L, Lubensky I, et al. Localization of the $92-\mathrm{kD}$ gelatinase mRNA in squamous cell and adenocarcinomas of the lung using in-situ hybridization. Am F Pathol 1994;144:518-27.

100 Buisson AC, Gilles C, Polette M, et al. Wound repairinduced expression of stromelysins is associated with the acquisition of a mesenchymal phenotype in human respiratory epithelial cells. Lab Invest 1996;74:658-69.

101 Bolon I, Brambilla E, Vandenbunder B, et al. Changes in the expression of matrix proteases and of the transcription factor c-Ets-1 during progression of precancerous bronchial lesions. Lab Invest 1996;75:1-13.

102 Newell KJ, Witty JP, Rodgers WH, et al. Expression and localization of matrix-degrading metalloproteinase during colorectal tumorigenesis. Mol Carcinog 1994;10:199-206.

103 Powell WC, Knox JD, Navre M, et al. Expression of the metalloproteinase matrilysin in DU-145 cells increases their invasive potential in severe combined immunodeficient mice. Cancer Res 1993;53:417-22.

104 Wilson CL, Heppner KJ, Labosky PA, et al. Intestinal tumorigenesis is suppressed in mice lacking the metalloproteinase matrilysin. Proc Nat Acad Sci USA 1997;94:1402-7.

105 Testa JE. Loss of the metastatic phenotype by a human epidermoid carcinoma cell line, HEp-3, is accompanied by increased expression of tissue inhibitor of metalloproteinase 2. Cancer Res 1992;52:5597-603.

106 Grignon DJ, Sakr W, Toth M, et al. High levels of tissue inhibitor of metalloproteinase-2 (TIMP-2) expression are associated with poor outcome in invasive bladder cancer. Cancer Res 1996;56:1654-9. 
107 Hewitt RE, Leach IH, Powe DG, et al. Distribution of collagenases and tissue inhibitors of metalloproteinases
(TIMP) in colorectal tumours. Int $\mathcal{f}$ Cancer 1991;49:66672 .

108 De Clerk YA, Perez N, Schimar H, et al. Inhibition of invasion and metastasis in cells transfected with an inhibitor of metalloproteinases. Cancer Res 1992;52:701-8.

109 Powe DG, Brough JL, Carter GI, et al. TIMP-3 mRNA expression is regionally increased in moderately and poorly differentiated colorect
1997; 75:1678-83.

110 Anand-Apte B, Pepper MS, Voest E, et al. Inhibition of angiogenesis by tissue inhibitor of metalloproteinase-3. Investig Ophthalmol Vis Sci 1997;38:817-23.

111 Saksela O, Rifkin DB. Release of basic fibroblast growth factor-heparan sulfate complexes from endothelial cells by plasminogen activator-mediated proteolytic activity. $\mathcal{f} \mathrm{Cell}$ Biol 1990;110:767-75.

112 Naldini L, Tamagnone L, Vigna E, et al. Extracellular proteolytic cleavage by urokinase is required for the activation of hepatocyte growth factor/scatter factor. EMBO $\mathcal{f}$ $1992 ; 11: 4825-33$.

113 Sato Y, Tsubo R, Lyons R, et al. Characterization of the activation of latent TGF- $\beta$ by co-cultures of endothelial cells and pericytes or smooth muscle cells: a self regulating system. F Biol Chem 1990;111:757-63.

114 Witty JP, McDonnell S, Newell K, et al. Modulation of matrilysin levels in colon carcinoma cell lines affect tumorigenicity in vivo. Cancer Res 1994;54:4805-12.

115 Morris VL, Koop S, MacDonald IC, et al. Mammary carcinoma cell lines of high and low metastatic potential differ not in extravasation but in subsequent migration and not in extravasation but in subsequent mign

116 Koop S, Khokha R, Schmidt EC, et al. Overexpression of metalloproteinase inhibitor in B16 F10 cells does not affect extravasation but reduces tumour growth. Cancer Res 1994;54:4791-7.

117 Khokha R, Zimmer MJ, Wilson SM, et al. Up-regulation of TIMP-1 expression in B16-F10 melanoma cells suppresses their metastatic ability in chick embryo. Clin Exp Metastasi 1992;32:365-70

118 Imren S, Kohn DB, Schimar H, et al. Over expression of tissue inhibitor of metalloproteinases- 2 by retroviral mediated gene transfer in vivo inhibits tumour growth and invasion. Cancer Res 1996;56:2891-5.

119 Wang M, Liu YE, Greene J, et al. Inhibition of tumour growth and metastasis of human breast cancer cells transfected with tissue inhibitor of metalloproteinase 4 . Oncogene 1997;14:2767-74.

120 Stetler-Stevenson WG, Krutsch FIC, Liotta LA. Tissue inhibitor of metalloproteinase (TIMP-2). f Biol Chem 1989;264:17374-8.

121 Hayakawa T, Yamashita K, Ohuchi E, et al. Cell growth-promoting activity of tissue inhibitor of metalloproteinases-2 (TIMP-2). F Cell Sci 1994;107:23739.

122 Bertaux B, Hornebeck W, Eisen AZ, et al. Growth stimulation of human keratinocytes by tissue inhibitor of metalloproteinases. F Invest Dermatol 1991;97:679-85.

123 Docherty AJP, Lyons A, Smith BJ, et al. Sequence of human tissue inhibitor of metalloproteinases and its identity to erythroid-potentiating activity. Nature $1985 ; 318$ 66-9.

124 Clark IM, Powell LK, Cawston TE. Tissue inhibitor of metalloproteinases (TIMP-1) stimulates secretion of collagenase from human skin fibroblasts. Biochem Biophys Res Comm 1994;203:874-80.

125 Boudreau N, Sympson CJ, Werb Z, et al. Suppression of ICE and apoptosis in mammary epithelial cells by extracelICE and apoptosis in mammary epith
lular matrix. Science 1995;267:891-5.

126 Bian J, Sun Y. Transcriptional activation by p53 of the human type IV collagenase (gelatinase A or matrix metallop

127 Ahonen M, Baker AH, Kahari V-M. Adenovirus-mediated gene delivery of tissue-inhibitor of metalloproteinases-3 inhibits invasion and induces apoptosis in melanoma cells. Cancer Res 1998;58:2310-5.

128 Baker AH, Zaltsman AB, George SJ, et al. Divergent effects of tissue inhibitors of metalloproteinase- $1,-2$ or -3 overexpression on rat vascular smooth muscle cell invasion, proliferation and death in vitro: TIMP-3 promotes apoptosis. F Clin Invest 1998;101:1478-87.

129 Bain J, Wang Y, Smith MR, et al. Suppression of in vivo tumour growth and induction of suspension cell death by
tissue inhibitor of metalloproteinases (TIMP)-3. Carcinotissue inhibitor of metallopr
genesis 1996;17:1805-11.

130 Smith MR, Kung H, Durum SK, et al. TIMP-3 induces cell death by stabilizing TNF- $\alpha$ receptors on the surface of human colon carcinoma cells. Cytokine 1997;9:770-80.

131 Ray CA, Black RA, Kronheim SR, et al. Viral inhibition of inflammation: cowpox virus encodes an inhibitor of the interleukin-1 $\beta$ converting enzyme. Cell 1992;69:597-604.

132 Billstrom A, Lecander I, Astedt B, et al. Recombinant PAI-2 inhibition of uPA-producing tumours in SCIDmice. Proceedings XIIth International Congress on Fibrinolysis 1994;8(Suppl 1):56.

133 Gleeson N, Gonsalves R, Bonnar J. The plasminogen activator urokinase and its inhibitor PAI-2 in endometrial canver. Gynecol Oncol 1992;47:58-61.

134 Weidner N, Folkman J, Pozza F, et al. Tumour angiogenesis: a new significant and independent prognostic indicator in early stage breast carcinoma. $\mathcal{F}$ Natl Cancer Inst 1992;84:1875-7.
135 Giatromanolaki A, Koukourakis M, O'Byrne K, et al. Prognostic value of angiogenesis in operable non-small cell Prognostic value of angiogenesis in op
lung cancer. F Pathol 1996;179:80-8.

136 Fontanini G, Vignati S, Bigini D, et al. Neoangiogenesis: a putative marker of malignancy in non-small-cell lung cancer (NSCLC) development. Int $\mathcal{F}$ Cancer 1996;67:615-9.

137 Takanami I, Tanaka F, Hashizume T, et al. Vascular endothelial growth factor and its receptor correlate with angiogenesis and survival in pulmonary adenocarcinoma. Anticancer Res 1997;17:2811-4.

138 Mattern J, Koomagi R, Volm M. Coexpression of VEGF and $\mathrm{bFGF}$ in human epidermoid lung carcinoma is associated with increased vessel density. Anticancer Res 1997;17: 2249-52.

139 Koukourakis MI, Giatromanolaki A, O’Byrne KJ, et al. Platelet-derived endothelial cell growth factor expression correlates with tumour angiogenesis and prognosis in noncorrelates with tumour angiogenesis and prognosis in

140 Koukourakis MI, Giatromanolaki A, O'Byrne KJ, et al. Potential role of bcl-2 as a suppressor of tumour angiogenesis in non-small cell lung cancer. Int 7 Cancer 1997;74:

141 Hildenbrand R, Dilger I, Horlin A, et al. Urokinase and macrophages in tumour angiogenesis. Br f Cancer 1995;72: 818-23.

142 Johnson MD, Kim H-RC, Chesler L, et al. Inhibition of angiogenesis by tissue inhibitor of metalloproteinases. $\mathcal{F}$ Cell Physiol 1994;160:194-202.

143 Itoh $\mathrm{T}$, Ikeda $\mathrm{T}$, Gomi $\mathrm{H}$, et al. Unaltered secretion of B-amyloid precursor in gelatinase A (matrix metalloproteinase-2)-deficient mice. $\mathcal{f}$ Biol Chem 1997;272: 22389-92.

144 Itoh $\mathrm{T}$, Tanioka $\mathrm{M}$, Yoshida $\mathrm{H}$, et al. Reduced angiogenesis and tumour progression in gelatinase A-deficient mice. Cer 1998;58:1048-51.

145 Kato Y, Nakayama Y, Umeda $\mathrm{M}$, et al. Induction of $103 \mathrm{kDa}$ gelatinase/type IV collagenase by acidic culture conditions in mouse metastatic melanoma cell lines. F Biol
Chem 1992;267:11424-30.

146 Schnaper HW, Grant DS, Stetler-Stevenson WG, et al. Type IV collagenase(s) and TIMPs modulate endothelial cell morphogenesis in vitro. $\mathcal{F}$ Cell Physiol 1993;156:23546

147 Takigawa M, Nishida Y, Suzuki F, et al. Induction of angiogenesis in chick yolk-sac membrane by polyamines and its inhibition by tissue inhibitors of metalloproteinases (TIMP-1 and TIMP-2). Biochem Biophys Res Commun 1990;171:1264-71.

148 Murphy AN, Unsworth EJ, Stetler-Stevenson WG. Tissueinhibitor of metalloproteinases-2 inhibits bFGF induced human microvascular endothelial cell proliferation. $\mathcal{f}$ Cell Physiol 1993;157:351-8.

149 Min HY, Doyle LV, Vitt CR, et al. Urokinase receptor antagonists inhibit angiogenesis and primary tumour growth in syngenic mice. Cancer Res 1996;56:2428-33.

150 Vlodavsky I, Fuks Z, Ashai-Michaeli R, et al. Extracellular matrix-resident basic fibroblast growth factor: implications for control of angiogenesis. F Cell Biochem 1991;47:167-76.

151 Pepper MS, Belin D, Montesano R, et al. Transforming growth factor-beta 1 modulates basic fibroblast growth endothelial cells in vitro. $\mathcal{f}$ Cell Biol 1990;111:743-55.

152 Levi E, Fridman R, Miao H-Q, et al. Matrix metalloproteinase 2 releases active soluble ectodomain of fibroblast growth facto

153 Gearing AJH, Beckett P, Christodoulou M, et al. Processing of tumor necrosis factor-alpha precursor by metalloproteinases. Nature 1994;370:555-7.

154 Crowe P, Walter BN, Mohler KM, et al. A metalloproteinase inhibitor blocks shedding of the $80 \mathrm{kD}$ TNF receptor and TNF processing in T lymphocytes. $f$ Exp Med 1995;181:1205-10.

155 Unemori EN, Ferrara N, Baurer EA, et al. Vascular endothelial growth factor induces interstitial collagenase expression in human endothelial cells. F Cell Physiol 1991;153:557-62.

156 Fisher C, Gilbertson-Beadling S, Powers EA, et al. Interstitial collagenase is required for angiogenesisin vitro. Dev Biol 1994;162:499-510.

157 Lamoreaux WJ, Fitzgerald MEC, Reiner A, et al. Vascular endothelial growth factor increases release of gelatinase A and decreases release of tissue inhibitor of metalloproteinases by microvascular endothelial cells in vitro. Microvascular Res 1998;55:29-42

158 Patterson BC, Sang QA. Angiostatin-converting enzyme activities of human matrilysin (MMP-7) and gelatinase B/type IV collagenase (MMP-9). F Biol Chem 1997;272: 28823-5.

159 Dong Z, Kumar R, Fidler IJ. Generation of the angiogenesis inhibitor, angiostatin, by Lewis lung carcinoma is mediated by macrophage elastase. Proc Am Assoc Cancer Res 1996;37:403a.

160 O'Reilly MS, Boehm T, Shing Y, et al. Endostatin: an endogenous inhibitor in angiogenesis and tumour growth. Cell 1997;88:277-85.

161 Ji WR, Barrientos LG, Llinas M, et al. Selective inhibition by kringle 5 of human plasminogen on endothelial cell migration, an important process in angiogenesis. Biochem Biophys Res Commun 1998;247:414-9.

162 O'Reilly MS, Holmgren L, Shing Y, et al. Angiostatin: a novel angiogenesis inhibitor that mediates the suppression of metastases by a Lewis lung carcinoma. Cell 1994;79: 315-28. 
163 Kusaka M, Sudo K, Matsutani E, et al. Cytostatic inhibition of endothelial cell growth by the angiogenic inhibitor TNPof endothelial cell growth by the angiogenic inh

164 Holmgren L, O'Reilly MS, Folkman J. Dormancy of micrometastases: balanced proliferation and apoptosis in the presence of angiogenesis suppression. Nature Med 1995;1:149-53.

165 Clifton F, Mountain MD. Revisions in the international system for staging lung cancer. Chest 1997;111:1711-7.

166 Duffy MJ. Plasminogen activators and cancer. Blood Coagul Fibrinolysis 1990;1:681-7.

167 Duffy MJ, O'Grady P, Devancy D, et al. Urokinaseplasminogen activator, a marker for aggressive breast cancers. Preliminary report. Cancer 1988;62:531-3.

168 Hasui Y, Marutsuka K, Suzumiya J, et al. The content of urokinase-type plasminogen activator as a prognostic factor in bladder cancer. Int 7 Cancer 1992;50:871-3.

169 Nekarda H, Siewert J, Schmitt M, et al. Tumour-associated proteolytic factors u-PA and PAI- 1 and survival in totally proteolytic factors u-PA and PAI-1 and surviva
resected gastric cancer. Lancet 1994;343:117.

170 Ganesh S, Sier CFM, Griffioen G, et al. Prognostic relevance of plasminogen activators and their inhibitors in relevance of plasminogen activators and their in
colorectal cancer. Cancer Res 1994;54:4065-71.

171 Kobayashi H, Fujishiro S, Terao T. Impact of urokinasetype plasminogen activator and its inhibitor type-1 on prognosis in cervical cancer of the uterus. Gynecol Oncol 1994;54:6539-48.

172 Kuhn W, Pache L, Schmalfeldt B, et al. Urokinase (uPA) and PAI-1 predict survival in advanced ovarian cancer patients (FIGO III) after radical and platinum-based chemotherapy. Gynecol Oncol 1994;55:401-9.

173 Hofmann R, Lehmer A, Buresch M, et al. Clinical relevance of urokinase plasminogen activator, its receptor, and its inhibitor in patients with renal cell carcinoma. Cancer 1996;78:487-92.

174 Duffy MJ, Reilly D, McDermott E, et al. Urokinase plasminogen activator as a prognostic marker in different plasminogen activator as a prognostic marker in different subgroup

175 Janicke F, Schmitt M, Pache L, et al. Urokinase plasminogen activator (u-PA) and its inhibitor PAI-1 are strong and
independent prognostic factors in node-negative breast independent prognostic factors in node-negative
cancer. Breast Cancer Res Treat 1993;53:135-44.

176 Oka T, Ishida T, Nishino T, et al. Immunohistochemical evidence of urokinase-type plasminogen activator in primary and metastatic tumours of pulmonary adenocarcinoma. Cancer Res 1991;51:3522-3.

177 Pedersen H, Grondahl-Hansen J, Francis D, et al. Urokinase and plasminogen activator inhibitor type-1 in pulmonary adenocarcinoma. Cancer Res 1994;54:120-3.

178 Nagayama M, Sato A, Hayakawa H, et al. Plasminogen activators and their inhibitors in non-small cell lung cancer. Low content of type 2 plasminogen activator inhibito associated with tumour dissemination. Cancer 1994;73: 1398-405.

179 Ganesh S, Sier CFM, Heerding MH, et al. Urokinase receptor and colorectal cancer survival. Lancet 1994;344: receptor

180 Duggan C, Maguire T, McDermott E, et al. Urokinase plasminogen activator and urokinase plasminogen activato receptor in breast cancer. Int $\mathcal{F}$ Cancer 1995;61:597-600. 181 Foekens JA, Schmitt M, van Putten WLJ, et al. Plasmino-
gen activator inhibitor-1 and prognosis in breast cancer. $\mathcal{F}$ Clin Oncol 1994;12:1648-58.

182 Pedersen H, Brunner N, Francis D, et al. Prognostic impact of urokinase, urokinase receptor and type-1 plasminogen activator inhibitor in squamous an

lung cancer tissue. Cancer Res 1994;54:4671-5.
Duggan C, Kennedy S, Kramer MD, et al. Plasmingen activator inhibitor type 2 in breast cancer. $B r f$ Cancer 1997;76:622-7.

184 Bouchet C, Spyratos F, Martin PM, et al. Prognostic value of urokinase plasminogen activator (uPA) and plasminogen activator inhibitors PAI-1 and PAI-2 in breast carcinomas. Br f Cancer 1994;69:398-405.

185 Takeuchi Y, Nakao A, Harada A, et al. Expression of plasminogen activators and their inhibitors in human pancreminogen activators and their inhibitors in human pancreatic carcinoma: im

186 Allam HS, Arand G, Lippman ME, et al. Association of MMP-2 activation potential with metastatic progression in human breast cancer cell lines independent of MMP-2 production. I Natl Cancer Inst 1993;85:1758-64.

187 Fong KM, Kida Y, Zimmerman PV, et al. TIMP-1 and adverse prognosis in non-small cell lung cancer. Clin Cancer Res 1996;2:1369-72.

188 Karameris A, Panagou P, Tsilalis T, et al. Association of expression of metalloproteinases and their inhibitors with the metastatic potential of squamous cell lung carcinomas. Am $\mathcal{F}$ Respir Crit Care Med 1997;156:1930-6.

189 Grignon DJ, Sakr W, Toth M, et al. High levels of tissue inhibitor of metalloproteinase-2 (TIMP-2) expression are associated with poor outcome in invasive bladder cancer. Cancer Res 1996;56:1654-9.

190 Ree AH, Florenes VA, Berg JP, et al. High levels of mRNA for tissue inhibitors of metalloproteinases (TIMP-1 and development of metastases. Clin Cancer Res 1997;3:1623-8.

191 Zeng ZS, Cohen AM, Zhang ZF, et al. Elevated tissue inhibitor of metalloproteinase-1 (TIMP-1) RNA in colorectal cancer stroma correlates with lymph node and distant metastasis. Clin Cancer Res 1995;1:899-906.

192 Davies B, Waxman J, Harpret W, et al. Levels of matrix metalloproteinases in bladder cancer correlate with tumour grade and invasion. Cancer Res 1993;53:1-5.

193 Brown PD, Giavazzi R. Matrix metalloproteinases inhibition: a review of anti-tumour activity. Ann Oncol 1995;6:967-74.

194 Chirivi RG, Garofalo A, Crimmin MJ, et al. Inhibition of the metastatic spread and growth of B16-BL6 murine melanoma by a synthetic matrix metalloproteinase inhibior. Int $\mathcal{F}$ Cancer 1994:58:460-4.

195 Eccles SA, Box GM, Court WJ, et al. Control of lymphatic and haematogenous metastasis of a rat mammary carcinoma by the matrix metalloproteinase inhibitor batimastat (BB-94). Cancer Res 1996;54:4726-8.

196 Taraboletti G, Gardfalo A, Belotti O, et al. Inhibition of angiogenesis and murine angioma growth by batimastat, a synthetic inhibitor of matrix metalloproteinases. 7 Natl Cancer Inst 1995;87:293-8.

197 Moses MA, Langer R. A metalloproteinase inhibitor as an inhibito

198 Tatbot DC, Brown PD. Experimental and clinical studies on the use of matrix metalloproteinase inhibitors for the on the use of matrix metalloproteinase inhibitors for

199 Hurewitz AN, Zucker S, Mancuso P, et al. Human pleural effusions are rich in matrix metalloproteinases. Chest 1992; $102: 1808-14$

200 Wojtowicz-Praga SM, Dickson RM, Hawkins MJ. Matrix metalloproteinase inhibitors. Invest NewDrugs 1997;15:6175 .

201 Rasmussen HS, McCann PP. Matrix metalloproteinase inhibition as a novel anticancer strategy: a review with special focus on batimastat and marimastat. Pharmacol Ther 1997;75:69-75.

202 An Z, Wang X, Willmott N, et al. An orally-active synthetic MMP inhibitor CT1746 reduces tumour spread and metastasis converting aggressive colonic cancer into a more indolent disease in a nude-mice model. Clin Exp Metastasis 1997; 15:184-95.

203 Anderson IC, Shipp MA, Docherty AJP, et al. Combinaion therapy including a gelatinase inhibitor and cytotoxic agent reduces local invasion and metastases of
Lewis lung carcinoma. Cancer Res 1996;56:715-20.

204 O'Reilly MS, Holmgren L, Chen C, et al. Angiostatin induces and sustains dormancy of primary tumours in mice. Nature Med 1996;2:689-92

205 Boehm T, Folkman J, Browder T, et al. Antiangiogenic therapy of experimental cancer does not induce acquired drug resistance. Nature 1997;390:404-7.

206 Weidner N, Folkman J, Pozza C, et al. Tumour angiogenesis: a new significant and independent prognostic indicator in early-stage breast carcinoma. F Natl Cancer Inst 1992;84:1875-87.

207 Fontanini G, Vignati S, Bigini D, et al. Microvessel count predicts metastatic disease and overall survival in nonpredicts metastatic disease and overall survival in

208 Stetler-Stevenson WG, Hewitt R, Corcoran M. Matrix metalloproteinases and tumour invasion: from correlation and causality to the clinic. Cancer Biol 1996;7:147-54. 